\title{
МЕНЕДЖМЕНТ «ПО-УКРӒ̈НСЬКИ»: ПРО ЯКІСТЬ ПІДГОТОВКИ УПРАВЛІНСЬКИХ КАДРІВ. ДУМКА НЕБАЙДУЖОГО
}

\author{
Наукова доповідь на методологічному семінарі НАПН України \\ "Шляхи і механізми підвищення конкурентоспроможності \\ університетів України» 19 листопада 2020 p.
}

https://doi.org/10.37472/2707-305X-2020-2-2-13-10

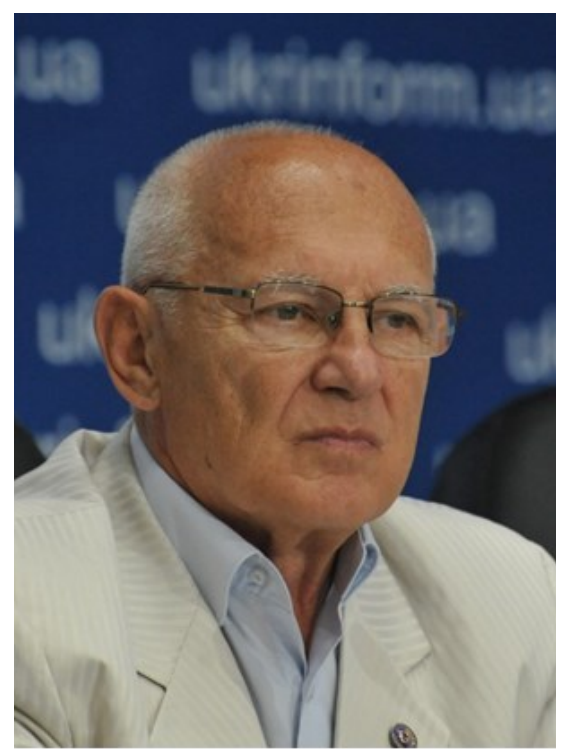

КАЛИТА ПЕТРО ЯКОВИЧ

кандидат технічних наук, старший науковий співробітник, президент Української асоціачії досконалості та якості, м. Київ, Україна
Анотація. у роботі вказано на ванливість сучасних систем менеджменту для розвитку України та акцентовано увагу на ролі менеднерів у побудові, підтримиі та удосконаленні таких систем. Проаналізовано стан підготовки менеджерів в Україні та виокремлено недоліки у чій справі. Основну увагу приділено аналізу визначення поняття «менеджент» у ДСТУ ISO 9000:2015 та тлумачень, пов'язаних із терміном «менеджмент» в українських наукових колах.

Ключові слова: менеджмент; управління; керівниитво; стандарти; системи менеджменту; менеджери.

Не існує країн слаборозвинених, єлише погано керовані.

Пітер Друкер

Усі наші успіхи і негаразди є результатами управлінських рішень, які ми приймаємо та втілюємо у життя. Це стосується і маленького підприємства, і великої компанії, а особливо органів влади.

В умовах глобалізованої насиченої економіки та жорсткої конкуренції ціна управлінських рішень дуже висока. Тому в розвинутих країнах і просунутих компаніях такі рішення формуються і приймаються у сучасних цілісних і збалансованих системах менедженту. Вони швидше і адекватніше реагують на ситуації, раніше за інших відчувають потребу у самовдосконаленні та приймають і втілюють у життя узгоджені та ефективні управлінські рішення.

Системи менеджменту та підготовка менеджерів. Сучасні системи менеджменту є складними і на відміну від систем управління технічними системами, їх не можна отримати ззовні «під ключ» для соціальної сфери. Кожна організація повинна створити свою унікальну систему менеджменту з допомогою підготовлених фахівців. I для цього більше за інших підходять менеджери. Саме тому необхідно звернути особливу увагу на менеджерів і якість їх підготовки в закладах освіти України.

Професійні знання, якими мають володіти сучасні менеджери, складаються з понятійного апарату, теорії та практики менеджменту. У цій роботі ми не будемо аналізувати теоретичну складову, яка традиційно і глибоко вивчається у закладах вищої освіти. Натомість основну увагу приділимо понятійному апарату та практичній частині, що має включати цільові системи менеджменту на базі стандартів, поза і понад норми стандартів, цілісні системи менеджмен- 
ту організацій та інженерію побудови сучасних систем менеджменту.

Термінологічні проблеми. Все починається 3 термінів та їх визначення. На важливість однакового розуміння термінів ще у XVII столітті звертав увагу видатний вчений Рене Декарт, який зазначив, що: "Люди позбулися б половини своїх неприємностей, якби змогли домовитись про значення термінів».

Проте, як засвідчив аналіз, в Україні у розумінні термінів у сфері менеджменту $є$ багато протиріч. Але основне з них - неправильний переклад міжнародного стандарту ISO 9000:2015 щодо визначення самого терміну «менеджмент». Це призвело до того, що українські вчені, які спеціалізуються на дослідженні та викладанні менеджменту, розуміють таке понятя переважно не зовсім адекватно: вважають, що «менеджмент» $\epsilon$ складовою «управління», а застосування терміну прийнятно лише для бізнесу тощо.

Проблеми щодо перекладу MC ISO 9000 в Україні. У Міжнародному стандарті ISO 9000:2015 «Системи управління якістю. Основні положення та словник термінів» дефініцію «менеджмент» (management) визначено у п. 3.3 як «coordinated activities to direct and control an organization» (3.2.1), «direct» перекладається як направляти, керувати (руководить - рос.), control управляти, зважаючи на те, що англомовний термін «control» більше застосовується як «управління», ніж «контроль», а для поняття «контроль» переважно використовується термін «monitoring». Тобто в стандарті ISO 9001:2015 у визначенні терміну «менеджмент», крім "управління», мається на увазі ще діяльність 3 «керівництва» або з установлення напрямів розвитку організації.

Тоді в перекладі українською «менеджмент» треба розуміти як скоординовану діяльність 3 «керівництва» та «управління» організацією. «Керівництво» здебільшого виражає спрямований характер діяльності людини або групи людей, під проводом яких (на чолі з якими) здійснюється діяльність певного колективу, та фокусується, насамперед, на визначенні напрямів розвитку організації. До основних функцій керівництва належить: визначення цінностей, цілей і культури організації; створення та впровадження в організації моделі управління тощо. Водночас управління $\epsilon$ діяльністю оперативного характеру і його функції спрямовані на досягнення цілей організації у межах встановленої керівництвом моделі та методології. У стандарті ISO 9001:2015 це відображено в циклі Демінга: плануй; роби; перевіряй; впливай.

Правильність такого тлумачення терміну «менеджмент» підтверджено і відповідним листом-роз'ясненням, який щойно надійшов на наш запит від імені ISO/TK-176 (розробника ISO 9000). До речі, у цьому листі зазначено, що офіційними мовами в ISO є англійська, французька та російська і наведено витяг із офіційної версії ГОСТ Р ИСО 9000-2015: п. 3.3.3 Менеджмент (management): «Скоординированная деятельность по руководству и управлению организацией (3.2.1)».

В українському ж стандарті ДСТУ ISO 9000:2015, який проголошено ідентичним стандарту ISO 9000:2015, п. 3.3.3. сформульовано так: «Управління; Керування (management) - це скоординовані дії щодо спрямовування та контролювання діяльності організації», що ніяк не можна назвати вдалим перекладом. Термін «менеджмент», який наведено в ISO 9000:2015 та широко застосовується в Україні (наприклад, назва спеціальності «Менеджмент»), не зрозуміло на яких підставах підмінено на «управління» і «керування», які визначено через «спрямовування» та «контролювання». Але при чому тут, наприклад, «контролювання»? Адже відомо, що це лише одна із функцій управління. А де тут планування та ін.? Логіку такого визначення взагалі пояснити важко. Такий переклад не відповідає стандарту ISO 9000:2015 і створює плутанину. При тому, що в самому формулюванні з ДСТУ ISO 9000:2015 вже закладено рівнозначність між поняттями «менеджент» (management) та «керування (керівництво) і управління». Слід відзначити, що помилкове визначення менеджменту вперше було закладено в ДСТУ не у 2015 р., а ще у 2001 р. і існує вже близько 20 років.

Ця принципова помилка стала причиною аналогічних негативних наслідків. Так, усі міжнародні стандарти, які мають назву «системи менеджменту» при їх «ідентичному» перекладі довелось «перейменовувати» із «систем менеджменту» на «системи управління». Найбільш цікаво це зроблено в стандарті ДСТУ ISO 21001:2019 «Освітні організації. Системи управління в освітніх організаціях. Вимоги та настанови щодо застосування (ISO 21001:2018, IDT)». У розділі «Терміни та визначення понять» записано: «п. 3.4 система управління; система менеджменту (management system) - це ...». 
Проблема щодо розуміння співвідношення термінів «менеджмент» $і$ «управління». 3 неправильним визначенням терміну «менеджмент» межує помилкове розуміння співвідношення термінів «менеджмент» і «управління».

Згідно, наприклад, із згаданим ДСТУ ISO 21001:2019 терміни «управління» і «менеджмент» $€$ синонімами, тобто вони рівнозначні. 3 іншого боку, Міністерством освіти і науки України (МOH України) у 2015 р. запроваджено галузь знань $07-$ «Управління та адміністрування», до якої включено спеціальність «Менеджмент». Цим визначено, що «менеджмент» $є$ складовою «Управління та адміністрування», чим і керуються всі причетні до підготовки фахівців за спеціальністю «Менеджмент». Це відображено в багатьох підручниках і монографіях (Хміль, 2003; Бесєдін \& Нагаєв, 2005; Гірняк \& Лазановський, 2000; Баєва та ін, 2007; Комарницький, 2016) (цікаво, що до 2015 р. така галузь знань мала назву саме «Менеджмент і адміністрування»). Натомість згідно з ISO 9000:2015 «менеджмент» - це «керівництво» та «управління». Тобто управління (як і керівництво) $\epsilon$ складовою менеджменту.

Річ у тім, що зі зростанням конкуренції для отримання додаткових конкурентних переваг постійно розвивались і удосконалювались процеси визначення місії організації, ії бачення, різні політики розвитку тощо. Це призвело до того, що така діяльність виокремилась і вже у 2000 р. у стандарті ISO 9000: 2000 у словнику з'явилось визначення терміну «менеджмент»: «скоординована діяльність з керівництва та управління організацією».

Термін «керівництво» в Україні не є новим. Ми неодноразово можемо почути: «під керівництвом уряду (дирекції) ми досягли успіху». На відміну від оперативного характеру «управління», керівництву властиві такі поняття, як: перспектива, стратегія, мета тощо.

Термін «управління» властивий одночасно як для технічних (наприклад, автомобіль, верстат), так і соціальних систем. Тому твердження, що управління у соціальній системі є складовою управління взагалі, має право на існування. Але, зважаючи, що «менеджмент» прийнятний лише для соціальних систем і $\in$ ширшим, ніж «управління», порівнювати його 3 терміном «управління» принаймні некоректно. Це як порівнювати автомобілі з двигунами.

Вже неодноразово опоненти запитували: «яка різниця, чи управління, чи менеджмент? Що від цього змінюється?». Змінюється і дуже. «Звуження» поняття «менеджмент» призводить до зниження уваги до керівництва, яке є основоположним для здійснення наступного управління. Саме через це в Україні не отримали належної уваги та сприймаються переважно формально такі сучасні процеси, як визначення місії, бачення, політик тощо, що впливають на формування корпоративної культури організації, ії досконалість і конкурентоспроможність.

Проблеми щодо сфери застосування терміну «менеджмент». В Україні поширене твердження, що термін «менеджмент» повинен застосовуватися лише в бізнесі, у комерційних організаціях, а для публічної сфери, зокрема для органів влади, цей термін є неприйнятним. МОН України запроваджено окрему галузь знань 28 - «Публічне управління та адміністрування», до якої включено спеціальність 287 - «Публічне управління та адміністрування», де жодного разу не вживається термін «менеджмент».

Але, як ми знаємо, у п. 3.3.3 Міжнародного стандарту ISO 9000:2015 зазначено, що менеджмент - це скоординована діяльність з керівництва та управління організацією (n. 3.2.1). У п. 3.2.1 ISO 9000:2015 (а одночасно і ДСТУ ISO 9000:2015) зазначено, що «організація» (organization) - це «особа або група осіб, що володіє своїми власними функціями з обов'язками, повноваженнями та взаємозв'язками для досягнення своїх цілей». Водночас примітка 1 до п. 3.2.1 уточнює, що: «поняття організація включає, але не обмежено цим - індивідуального підприємця, компанію, корпорацію, фірму, підприємство, орган влади, партнерство, асоціацію ...». Тобто в стандарті од нозначно сказано, що термін «менеджмент» розповсюджується також і на публічну сферу, зокрема на органи влади.

Це, так би мовити, з формальної позиції. Але давайте розглянемо питання ще й по суті. Публічний сектор включає установи центральної, регіональної та місцевої влади, публічні корпорації, а також самоврядні недержавні неприбуткові організації громадян, які створюють публічні сервіси, зокрема з освіти та охорони здоров'я. Чим же вони відрізняються від організацій приватного сектору в тому аспекті, який ми розглядаємо? Хіба вони, крім оперативного управління, не здійснюють ще й керівництво своїми організаціями? Чи вони не повинні розробляти для себе місію і бачення, визначати цінності, зокрема ставлення до цілей сталого розвитку та принципів соціаль- 
ної відповідальності, політики, перспективи свого розвитку, стратегічні цілі, моделі управління тощо? A, якщо повинні, то якраз ми і маємо «керівництво» та «управління», що в сукупності і $€$ «менеджмент».

На окрему увагу заслуговують органи державної влади. Адже вони, крім того, що повинні підтримувати ефективну діяльність всередині своєї установи, мають ще забезпечувати розвиток закріплених за ними сфер життєдіяльності країни. Візьмемо, наприклад, Міністерство розвитку економіки, торгівлі та сільського господарства України. Це величезна установа зі складною структурою, апарат якої нараховує понад тисячу осіб. । тут для наведення ладу, безумовно, має бути своя ефективна система менеджменту (умовно перший контур керівництва і управління). Мінекономіки є головним органом у системі центральних органів виконавчої влади із забезпечення формування та реалізації державної економічної, цінової, інвестиційної та зовнішньоекономічної політики. Воно узагальнює практику застосування законодавства і розробляє пропозиції щодо його удосконалення, проєкти нормативно-правових актів, організовує виконання актів законодавства, здійснює контроль за їх реалізацією. До основних завдань Мінекономіки належать: формування та реалізація державних політик і стратегій розвитку економіки, прогнозування та державне регулювання національної економіки тощо. І це також має бути відображено у системі менеджменту міністерства (другий контур керівництва і управління). Те саме можна сказати і про інші органи влади, зокрема Міністерство освіти і науки України, яке $\epsilon$ головним органом у системі центральних органів виконавчої влади, що забезпечує формування та реалізує державну політику у сферах освіти і науки.

До речі, багато українських організацій публічного сектору, зокрема й органів центральної, регіональної та місцевої влади, вже давно запровадили у себе систему менеджменту якості відповідно до ISO 9001.

Якщо ж вважати, що менеджмент таки не прийнятний для публічного сектору, то дуже цікаво, як у цьому секторі планують впровадити, наприклад, такий найактуальніший для України та її влади державний стандарт України, як ДСТУ ISO 37001:2018 «Системи управління щодо протидії корупції. Вимоги та настанови щодо застосування (ISO 37001:2016, IDT)», що вже введений в дію 3 1 січня 2020 р.? Адже сам міжнародний стандарт
ISO 37001:2016 має назву «Anti-bribery manage-

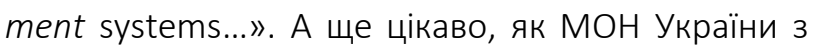
1 січня 2021 р. впроваджуватиме у сфері освіти державний стандарт України дСTУ ISO 21001:2019. У той час, як ця сфера також належить переважно до публічного сектору, а справжня назва ISO 21001:2018 - Educational organizations - Management systems...

Здається, що для кращого розуміння корисно взагалі ознайомитись з історією появи поняття «менеджмент» в ISO 9000 та врахування його в Україні.

У стандартах ISO 9000:1987 та ISO 9000:1994 ще не було свого словника і щодо застосованих термінів вони посилались на ISO 8402 «Управління якістю та забезпечення якості» Словник. Так, у стандарті ISO 9000:1994 було посилання на ISO 8402-94, в якому взагалі ще не згадувався термін «менеджмент». Тут у п. 3.4 було тільки наведено визначення терміну «управління»: «методи та види діяльності оперативного характеру, що використовуються для виконання встановлених вимог».

I тільки у стандарті ISO 9000:2000 з'явився власний словник, в якому вперше було надано визначення терміну «менеджмент». Тобто, визначенню терміну «менеджмент» вже виповнилось 20 років. В Україні цей термін було введено офіційно у 2001 р. через «ідентичний» переклад ISO 9000:2000 і представлення його вже як державного стандарту України ДСТУ ISO 9000:2001.

Зрозуміло, що в наукових працях можна визначати терміни по-різному. Але, якщо на міжнародному рівні (в ISO) щодо терміну дійшла згоди більшість країн, зокрема, вчених, які ці країни представляли, то маємо поважати спільний розум і прийняти у сфері освіти цей термін як основний. Для України це особливо важливо, адже вона прагне інтегруватися в європейську і світову спільноти.

I постає низка запитань. Як могло статися, що в Україні при введенні міжнародних стандартів ISO серії 9000 таке фундаментальне поняття, як «менеджмент», визначено неправильно, але ніхто з учених, викладачів і фахівців з менеджменту не звернув на це уваги? Чому вища школа, яка готує для України менеджерів, вже 19 років поспіль не дотримується міжнародних стандартів з менеджменту? Міжнародна організація зі стандартизації ISO об'єднує 164 країни з усього світу, вибудувала єдину цілісну збалансовану систему термінів та їх визначень у сфері системного менеджменту, а Україна, яка є членом ISO, ігнорує її стандарти? 
Особливо це стосується Мінекономіки, яке «забезпечує формування і реалізує державну політику у сфері стандартизації» та МОН України. І чому керівники цих відомств не реагують на відповідні звернення професійної громадськості, які вони отримують уже протягом багатьох років?

Організаційні проблеми. Але особливої шкоди Україні завдано хибною Концепцією державної політики з управління якістю продукції, яку розробив Держстандарт, не розібравшись у проблемі. У 2002 р. Концепція була затверджена Кабінетом Міністрів України.

Концепція поєднувала в собі несумісне, на кшталт «копати від паркану й до обіду». У ній сплутані поняття: «якість продукції» і «система менеджменту організації». У Концепції звужено орієнтацію на забезпечення якості продукції. Водночас під «управління якістю продукції» не аргументовано підведено цільові системи менеджменту, які не мають відношення до якості продукції (екологічний менеджмент, менеджмент професійної безпеки, менеджмент енергоефективності та ін.). А головне - Концепція створила плутанину у підготовці фахівців з менеджменту у закладах вищої освіти України.

Проблема розщеплення навчання з менеджменту. Відповідно до Концепції в українських закладах вищої освіти почало здійснюватися неадекватне навчання системного менеджменту і ділової досконалості. Так, за спеціальністю «Якість, стандартизація та сертифікація» під «якістю» також почали розуміти «управління якістю». Сюди ж додавалися цільові системи менеджменту, властиві насиченому ринку, на які приймалися міжнародні стандарти, що не мали відношення до управління якістю продукції. Але найгірше, що одночасно зі спеціальності «Менеджмент» питання про цільові системи менеджменту та інженерію їх проєктування були майже виключені. Це призвело до того, що й сьогодні заклади вищої освіти випускають менеджерів, недостатньо підготовлених для забезпечення успішності організацій в умовах жорсткої конкуренції. А фахівці, які навчаються за спеціальністю «Якість, стандартизація та сертифікація», не здатні ефективно вдосконалювати системи менеджменту організацій через відсутність базової підготовки з основ менеджменту. Крім того, за цією спеціальністю студентів навчали лише відповідно до стандартів, не враховуючи, що в умовах насиченого ринку стандарти відображають лише мінімальні вимоги, зокрема до систем менеджменту, а конкуренція відбувається переважно вище норм, встановлених стандартами.

Це призвело до того, що навіть ті організації, які удосконалюються на засадах стандартів на системи менеджменту, мають типові недоліки. Вони переважно створюють окремі ізольовані цільові системи менеджменту, не узгоджені між собою, не інтегровані у загальну систему менеджменту організації, не охоплюють усіх ії цілей. Майже не застосовують сучасні методи і інструменти підготовки управлінських рішень. Часто впроваджують системи менеджменту формально, без зміни застарілої ділової культури. Не враховують, що в умовах насиченого ринку норми стандарту - то лише мінімальний рівень вимог.

І хоч у 2019 р. на довготривалі вимоги громадськості Концепцію відмінили, але плутанина в організації підготовки менеджерів трапляється ще й досі.

\section{СПИСОК ВИКОРИСТАНИХ ДЖЕРЕЛ}

Баєва, О.В., Новальська, Н.І., \& Згалат-Лозинська, Л.О. (2007). Основи менеджменту: практикум : навчальний посібник. Київ: Центр учбової літератури.

Бесєдін, М.О., \& Нагаєв, В.М. (2005). Основи менеджменту: оцінно-ситуаційний підхід (модульний варіант) : підручник. Київ: Центр навчальної літератури.

Гірняк, О.М., \& Лазановський, П.П. (2000). Менеджмент. Теоретичні основи і практикум: навчальний посібник для студентів вищих закладів освіти. Київ: Магнолія плюс, Львів: Новий світ.

Друкер, П. (2012). Менеджмент. Вызовы XXI века. (Н. Макарова, пер. с англ.). Москва: Манн, Иванов и Фербер.

ДСТУ ISO 9000-2001. Системи управління якістю. Основні положення та словник. (2001). Держстандарт України.

ДСТУ ISO 9000:2007. Системи управління якістю основні положення та словник термінів. (2008). Держспоживстандарт України.

ДСТУ ISO 9000:2015 СИстеми управління якістю. Основні положення та словник термінів. (2015). Науково-дослідний інститут метрології вимірювальних і управляючих систем (ДП «НДІ «Система»).

Калита, П.Я. (2020). Підготовка менеджерів в Україні. Педагогічна газета, (3).

Калита, П.Я. (2018). Ціна (не)якості. ZN.UA, (8-9).

Комарницький, І.Ф. (2016). Економічна теорія. Чернівці.

Хміль, Ф.І. (2003). Основи менеджменту : підручник. Київ: Академвидав.

ISO 9001:1987. Quality systems - Model for quality assurance in design / development, production, installation and servicing. (1987). https://www.iso.org/ standard/16533.html

ISO 9004:2000. Quality management systems - Guidelines for performance improvements. (2000). https:// www.iso.org/standard/28692.html 
ISO 9000:2005. Quality management systems - Fundamentals and vocabulary. (2005). https://www.iso.org/ standard/42180.html
ISO 9000:2015. Quality management systems - Fundamentals and vocabulary. (2015). https://www.iso.org/ standard/45481.html

\section{MANAGEMENT "IN UKRAINIAN": ON THE QUALITY OF \\ MANAGERS' TRAINING. THE OPINION OF A CARING PERSON}

Scientific report at the methodological seminar of the National Academy of Educational Sciences of Ukraine "Ways and Mechanisms of Increasing the Competitiveness of Universities", November 19, 2020

\section{Petro Kalyta}

PhD in Engineering, Senior Researcher, President, Ukrainian Association for Excellence and Quality, Kyiv, Ukraine

Abstract. The importance of modern management systems for the development of Ukraine are pointed out in the report. The emphasis is placed on the role of managers in building, supporting and improving such systems. The state of managers' training in Ukraine is analysed and shortcomings are highlighted. The main attention is paid to the analysis of the definition of "management" in the State Standard of Ukraine ISO 9000:2015 and interpretations related to the term "management" in Ukrainian academia.

Keywords: management; control; direct; standards; management systems; managers.

Дата публікації: 31 грудня 2020 р. 